\title{
FORMULATION DEVELOPMENT AND STABILITY INDICATING HPLC ASSAY OF TABLETS OF APIXABAN
}

\author{
HEMANT K. JAIN*, VISHAL K. NIKAM
}

Department of Quality Assurance Techniques, Sinhgad College of Pharmacy, Vadgaon (Bk.), Pune 411041, Maharashtra, India Email: hemantkjain2001@yahoo.co.in

Received: 29 May 2017 Revised and Accepted: 31 Aug 2017

\section{ABSTRACT}

Objective: Cost effective formulation development and stability indicating HPLC method for estimation of apixaban in bulk and tablets dosage form.

Methods: $3^{2}$ factorial design was applied to formulate the immediate release tablets of apixaban by using direct compression method. The chromatographic separation was performed on Purospher Star RP-18e (5 $\mu \mathrm{m}, 250 \mathrm{x} 4,6 \mathrm{~mm})$ column and a stability indicating assay method was developed by using HPLC. The mobile phase consists of water: acetonitrile $(60: 40 \mathrm{v} / \mathrm{v})$ was delivered at a flow rate of $1 \mathrm{ml} / \mathrm{min}$ and UV detection at $280 \mathrm{~nm}$. The method was validated with forced degradation studies as per ICH guidelines.

Results: Prepared batches were evaluated for all pre-compression parameters and post-compression parameters. Formulation batch F5 prepared by direct compression shows highest dissolution release of $90.97 \%$ over the period of 60 min while disintegration time was found to be 136 seconds. The retention time of developed HPLC method was found to be 5.66 min. This method was found to be linear in a concentration range of $5-$ $30 \mu \mathrm{g} / \mathrm{ml}$ of the drug $\left(\mathrm{r}^{2}=0.999\right)$. The low value of \% RSD in the precision study indicates reproducibility of the method. The low value of LOD and LOQ suggests the sensitivity of the method. The results of forced degradation studies indicated that the drug was less stable in thermal and photolytic condition and degraded in acidic, basic, oxidative conditions.

Conclusion: On the basis of formulation evaluation, batch F5 was found to be promising formulation suitable for the immediate release of apixaban. Results obtained by validation studies suggested that the developed stability indicating assay method is simple, accurate, specific, sensitive and precise. Thus, this method can be used for routine analysis of apixaban formulation and to check the stability testing.

Keywords: Apixaban, Formulation Development, Tablets, RP-HPLC, Stability indicating assay method, Method validation

(C) 2017 The Authors. Published by Innovare Academic Sciences Pvt Ltd. This is an open-access article under the CC BY license (http://creativecommons.org/licenses/by/4.0/) DOI: http://dx.doi.org/10.22159/ijpps.2017v9i10.20343

\section{INTRODUCTION}

Apixaban (fig. 1) [4] is chemically 1-(4-methoxyphenyl)-7-oxo-6-[4(2-oxopiperidin-1-yl) phenyl]-4,5,6,7-tetrahydro-1H-pyrazolo[3,4c]pyridine-3-carboxamide. It is a new generation of oral anticoagulant drug that selectively inhibits coagulation factor Xa [1]. It is used in thromboprophylaxis in patients following total knee replacement surgery with a desired efficacy and safety profile [2]. FDA approved apixaban (Eliquis, Bristol-Myers Squibb/Pfizer) on December 28, 2012, for the prevention of stroke and systemic embolism in patients with nonvalvular atrial fibrillation (AF) [3] Apixaban is not an official drug in any Pharmacopoeia. Literature survey reveals that only one marketed formulation of apixaban is available which is very costly and cannot afford to poor patients. Therefore, a cost-effective formulation as compared to the marketed formulation is developed. Some methods have been reported for their determination of apixaban by HPLC [4-6] and hyphenated techniques such as UPLC-MS/MS [7-8], LCMS [9-10], GCMS [11] either alone or in combination. This paper presents formulation development of apixaban as well as development and validation of stability indicating assay method by using the RP-HPLC technique.

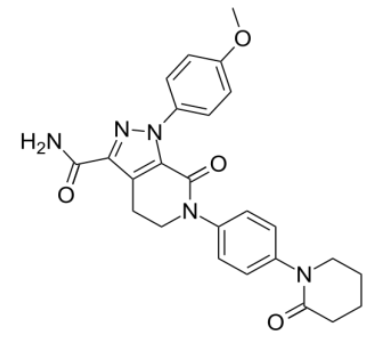

Fig. 1: Chemical structure of apixaban

\section{MATERIALS AND METHODS}

\section{Materials}

Commercially available tablets of apixaban (Eliquis ${ }^{\circledR}$ contain $5 \mathrm{mg}$ ) were procured from local market and apixaban API was obtained from an approved supplier. All excipients were obtained from Loba Chemie Pvt. Ltd., Mumbai, India. HPLC grade solvents used in this study were obtained from Merck Specialties Pvt. Ltd., Mumbai.

\section{Instruments}

Apixaban tablets were formulated on single punch tablet compression machine Mini press 1 (Karnavati Engineering limited). The friability test was performed on Electrolab EF-2 friabilator USP. Disintegration test was performed on Electrolab disintegration tester ED-2L. The dissolution testing was performed on Labindia DS 8000. The method was performed on Shimadzu LC 2010 CHT, Japan having a quaternary system with automatic injection facility and UVVisible detection system. The column used was Purospher Star RP18e (5 $\mu \mathrm{m}, 250 \mathrm{x} 4,6 \mathrm{~mm})$, LC solution software and Shimadzu AY120 balance was used for this work.

\section{Formulation of tablets}

Before formulation and pre-formulation studies (organoleptic properties, solubility, and drug excipient compatibility studies) were carried out. Apixaban tablets were formulated by using $3^{2}$ factorial design as presented in table 1 . Drug, binder, superdisintegrant and other excipients were weighed separately for 60 tablets per batch as per proposed formulations. The proposed formulations were coded as F1, F2, F3, F4, F5, F6, F7, F8 and F9. The amounts of drug and excipients are expressed in $\mathrm{mg}$ (milligram) unit. Initially, the binder, super-disintegrant and other excipients were passed through sieve no. 40. Then, apixaban (API) was added, mixed properly for 5-10 min and sieved again. Blended 
mass was taken in the hopper and then die and punch were adjusted to get the desired weight of the tablet $(100 \mathrm{mg})$. Tablets were prepared using flat face round $6.5 \mathrm{~mm}$ diameter punch by the direct compression process.

Table 1: Batches designed by using $\mathbf{3}^{\mathbf{2}}$ factorial design

\begin{tabular}{|c|c|c|c|c|c|c|c|c|c|}
\hline \multirow[t]{2}{*}{ Ingredients } & \multicolumn{9}{|c|}{ Formulation code (mg/tablet) } \\
\hline & F1 & F2 & F3 & F4 & F5 & F6 & F7 & F8 & F9 \\
\hline Apixaban & 5 & 5 & 5 & 5 & 5 & 5 & 5 & 5 & 5 \\
\hline Lactose & 49 & 54 & 44 & 40 & 50 & 45 & 47 & 42 & 52 \\
\hline Microcrystalline Cellulose & 30 & 30 & 30 & 30 & 30 & 30 & 30 & 30 & 30 \\
\hline Croscarmellose Sodium & 3 & 3 & 3 & 7 & 7 & 7 & 5 & 5 & 5 \\
\hline Magnesium Stearate & 2 & 2 & 2 & 2 & 2 & 2 & 2 & 2 & 2 \\
\hline PVPK-30 & 10 & 5 & 15 & 15 & 5 & 10 & 10 & 15 & 5 \\
\hline SLS & 1 & 1 & 1 & 1 & 1 & 1 & 1 & 1 & 1 \\
\hline
\end{tabular}

\section{Evaluation of powder blend}

\section{Angle of repose}

The angle of repose $(\theta)$ was determined using fixed funnel method. The height of the funnel was adjusted in such a way that the tip of the funnel just touched the apex of the heap of the granules. The granules were allowed to flow through the funnel freely onto the surface. The diameter of the granular cone was measured and angle of repose was calculated using the following equation.

$$
\theta=\tan ^{-1}\left(\frac{\mathrm{h}}{\mathrm{r}}\right)
$$

Where $\mathrm{h}$ and $\mathrm{r}$ are the height and radius of the cone.

\section{Bulk density}

Bulk density was determined by pouring a weighed quantity of tablet blend into a graduated cylinder and measuring the height. Bulk density was calculated using the following equation.

$$
\text { Bulk density }=\frac{\mathrm{m}}{\mathrm{v}}=\frac{\mathrm{m}}{\pi \mathrm{r} 2 \mathrm{~h}}
$$

Where $\mathrm{m}$ is weight of powder $(\mathrm{g}), \mathrm{v}$ is bulk volume $\left(\mathrm{cm}^{3}\right), \mathrm{r}$ is radius of cylinder $(\mathrm{cm})$ and $\mathrm{h}$ is height reached by powder in cylinder $(\mathrm{cm})$

\section{Tapped density}

Tapped density is the ratio of the mass of tablet blend to the tapped volume of tablet blend. Tablet blend was poured into graduated cylinder. Then, the cylinder was allowed to 100 taps under its own weight onto a hard surface. Tapped density was calculated using following equation.

$$
\text { Tapped density }=\frac{\mathrm{m}}{\mathrm{v}}=\frac{\mathrm{m}}{\pi \mathrm{r} 2 \mathrm{~h}}
$$

Where $\mathrm{m}$ is weight of powder $(\mathrm{g}), \mathrm{v}$ is Tapped Volume $\left(\mathrm{cm}^{3}\right), \mathrm{r}$ is radius of cylinder $(\mathrm{cm})$ and $h$ is height reached by powder in cylinder after tapping $(\mathrm{cm})$

\section{Hausner's ratio:}

Hausner's ratio indicates the flow properties of the powder and measured by the ratio of tapped density to bulk density. Hausner's ratio was determined by the given formula

$$
\text { Hausner's Ratio }=\frac{\text { Tapped density }}{\text { bulk density }}
$$

\section{Carr's compressibility index}

Compressibility is the ability of the powder to decrease in volume under pressure using bulk density and tapped density. It is indirectly related to the relative flow rate. Carr's compressibility index was determined by the following formula

$$
\text { Carr's Index }(\%)=\left(1-\frac{\text { Bulk density }}{\text { Tapped density }}\right) \times 100
$$

\section{Evaluation of tablets}

\section{Appearance}

The general appearance of the tablet was observed for elegance, shape, color, surface textures.

\section{Tablet thickness}

The thickness of the tablets was determined by using Vernier calipers. Randomly, 5 tablets selected from each formulation were used for determination of thickness.

\section{Tablet Hardness}

The tablet crushing load, which is the force required to break a tablet by compression. The hardness of the 5 tablets (Randomly selected) was determined by diametral compression using Pfizer hardness tester.

\section{Weight variation test}

The weight of 20 tablets was determined individually and average weight was calculated. Weight control test is based on Indian Pharmacopoeia

\section{Tablet friability}

The friability of the tablets was measured in an Electrolab EF-2 friabilator (USP). A sample of 10 tablets are dedusted in a drum for a fixed time (100 revolutions) and weighed again. Percentage friability was calculated from the loss in weight as given in equation as below.

$$
\% \text { of friability }=\mathrm{W}_{0}-\mathrm{W}_{1} / \mathrm{W}_{0} \times 100
$$

Where $\% \mathrm{f}$ is percentage friability, $\mathrm{W}_{0}$ is initial weight and $\mathrm{W}_{1}$ is final weight of tablets

\section{Disintegration test}

This study was conducted by using disintegration test apparatus on Electrolab disintegration tester ED-2L. The apparatus consists of six plastic tubes which are open at one end and another end is fitted with a rust-proof mesh No. 10. The tubes were suspended in 1-litre phosphate buffer solution ( $\mathrm{pH}$ 6.8) at a temperature of $37^{\circ} \mathrm{C}$. The plastic tubes were allowed to move up and down at a constant rate through a distance of 53-57 $\mathrm{mm}$. The test was carried out for each formulation batch (six tablets) and the disintegration times were noted.

\section{Drug content uniformity}

10 tablets were weighted and an average weight of one tablet was calculated. These tablets were crushed and powder equivalent to one tablet was weighed and dissolved in diluent [water: acetonitrile $(60: 40 \mathrm{v} / \mathrm{v})]$. This solution was filtered through Whatman filter paper no 41 and further diluted suitably. Then, the solution was injected into HPLC system.

\section{In vitro dissolution study}

Dissolution studies of each batch were conducted according to USP apparatus II paddle method with $900 \mathrm{ml}$ phosphate buffer ( $\mathrm{pH}$ 6.8) at $37{ }^{\circ} \mathrm{C}$ and $75 \mathrm{rpm}$. After $5,10,20,30,45$ and 60 min interval samples $(10 \mathrm{ml}$ each) were withdrawn from the dissolution medium and replaced with fresh medium to maintain a constant volume. The samples were filtered through a $0.45 \mu$ membrane filter. Then samples were diluted to a suitable concentration with phosphate buffer ( $\mathrm{pH}$ 6.8). Then, the solution was injected into HPLC system. The cumulative percentage of drug release was calculated [12-15]. 


\section{Assay of tablets}

Twenty tablets were weighed and average weight was calculated. These tablets were crushed and powdered in a glass mortar. The tablet powder equivalent to the average weight of apixaban was accurately weighed, transferred to a $50 \mathrm{ml}$ of volumetric flask and diluted up to mark with water: acetonitrile $(60: 40 \mathrm{v} / \mathrm{v})$. The solution was filtered through Whatman filter paper no. 41. This solution was further diluted to obtain $30 \mu \mathrm{g} / \mathrm{ml}$ with diluent and the sample solution was injected into HPLC system. This procedure was repeated in triplicate.

\section{Forced degradation studies}

To evaluate stability, apixaban was subjected to force degradation under the condition of acid, base, neutral hydrolysis and oxidation as per international conference on harmonization (ICH) guidelines [16-19].

\section{Acid hydrolysis}

$100 \mathrm{mg}$ of apixaban was weighed accurately and transferred to 100 $\mathrm{ml}$ volumetric flask containing $100 \mathrm{ml}$ of $0.1 \mathrm{~N}$ hydrochloric acid $(\mathrm{HCl})$. This mixture was refluxed at $80{ }^{\circ} \mathrm{C}$. After $2 \mathrm{~h}, 5 \mathrm{ml}$ of refluxed sample was withdrawn and neutralized with $5 \mathrm{ml}$ of $0.1 \mathrm{~N}$ sodium hydroxide. This solution was further diluted 10 times with mobile phase to obtain a concentration of $100 \mu \mathrm{g} / \mathrm{ml}$. The chromatogram obtained after $2 \mathrm{~h}$ of acid hydrolysis is shown in fig. 6(a).

\section{Alkaline hydrolysis}

$100 \mathrm{mg}$ of apixaban was weighed accurately and transferred to $100 \mathrm{ml}$ volumetric flask containing $100 \mathrm{ml}$ of $0.1 \mathrm{~N}$ sodium hydroxide $(\mathrm{NaOH})$. This mixture was refluxed at $80^{\circ} \mathrm{C}$. After $2 \mathrm{~h}$, $5 \mathrm{ml}$ of refluxed sample was withdrawn and neutralized with 5 $\mathrm{ml}$ of $0.1 \mathrm{~N}$ hydrochloric acid. This solution was further diluted 10 times with mobile phase to obtain a concentration of 100 $\mu \mathrm{g} / \mathrm{ml}$. The chromatogram obtained after $2 \mathrm{~h}$ of alkali hydrolysis is shown in fig. 6(b).

\section{Oxidative degradation}

$100 \mathrm{mg}$ of apixaban was weighed accurately and transferred to $100 \mathrm{ml}$ volumetric flask containing $100 \mathrm{ml}$ of $3 \%$ hydrogen peroxide (H2O2). This mixture was refluxed at $80^{\circ} \mathrm{C}$. After $2 \mathrm{~h}, 5$ $\mathrm{ml}$ of refluxed sample was withdrawn. This solution was further diluted 10 times with mobile phase to obtain a concentration of $100 \mu \mathrm{g} / \mathrm{ml}$. The chromatogram obtained after $2 \mathrm{~h}$ of oxidative degradation is shown in fig. 6(c).

\section{Thermal degradation}

$100 \mathrm{mg}$ of apixaban IR tablet powder sample was weighed and transferred into $100 \mathrm{ml}$ volumetric flask. The contents were refluxed as such on a water bath previously maintained at $80 \mathrm{C}$ for $2 \mathrm{~h}$. The sample was allowed to cool to room temperature and then the volume was made up to the mark with mobile phase and mixed well. The solution was filtered through a $0.45 \mu$ syringe filter and analyzed. The chromatogram obtained after $2 \mathrm{~h}$ of thermal degradation is shown in fig. 6(d).

\section{Photolytic degradation}

Photolytic degradation of the drug was carried out by exposure of about $100 \mathrm{mg}$ of apixaban IR tablet powder sample to UV radiation for $12 \mathrm{~h}$. Then the sample was transferred into $100 \mathrm{ml}$ volumetric flask. The sample was allowed to cool to room temperature and then the volume was made up to the mark with mobile phase and mixed well. The solution was filtered through a $0.45 \mu$ syringe filter and analyzed. The chromatogram obtained after $12 \mathrm{~h}$ of photolytic degradation is shown in fig. 6(e).

\section{Validation of the method}

The developed chromatographic method was validated for system suitability, linearity, range, accuracy, precision, LOD-LOQ and robustness parameters as per ICH guidelines [20-23].

\section{Linearity and range}

Working standard solutions were injected in the range of 5-30 $\mu \mathrm{g} / \mathrm{ml}$ under the optimized chromatographic conditions and peak areas were calculated at $280 \mathrm{~nm}$. The calibration curve was plotted between areas against concentrations of the drug. Linear regression data, as well as calibration curve, were shown in fig. 7.

\section{Precision}

Repeatability study was carried out with six replicates and intermediate precision studies were carried out with three concentrations of apixaban with three replicates. The values of $\%$ relative standard deviation (\% RSD) of precision study are shown in table 9.

\section{Accuracy}

The accuracy of the method was determined by calculating percent recovery of the drug by standard addition method. Percent recovery of apixaban was determined at three different level $80 \%, 100 \%$, and $120 \%$ of the target concentration in triplicate. The results of accuracy study are shown in table 10 .

\section{Robustness}

Robustness of the optimized method was studied by changing flow rate $( \pm 0.1 \mathrm{ml} / \mathrm{min})$, change in wavelength $( \pm 1 \mathrm{~nm})$ and change in mobile phase composition $( \pm 5 \%)$ during analysis. The sample was injected in triplicate for every condition and \% RSD was calculated for each condition is shown in table 11.

\section{Limit of detection (LOD) and limit of quantitation (LOQ)}

Five sets of concentrations were prepared between $5-30 \mu \mathrm{g} / \mathrm{ml}$ and the corresponding areas of these sets were measured. Calibration curves were plotted for each set. The standard deviation of the yintercept and average slope of the calibration curve was used to calculate LOD and LOQ using following formulae.

$$
\mathrm{LOD}=\frac{3.3 \times \mathrm{SD}}{\mathrm{S}} \mathrm{LOQ}=\frac{10 \times \mathrm{SD}}{\mathrm{S}}
$$

Where SD is the standard deviation of y-intercepts of the calibration curves; $S$ is the mean slope of six calibration curves.

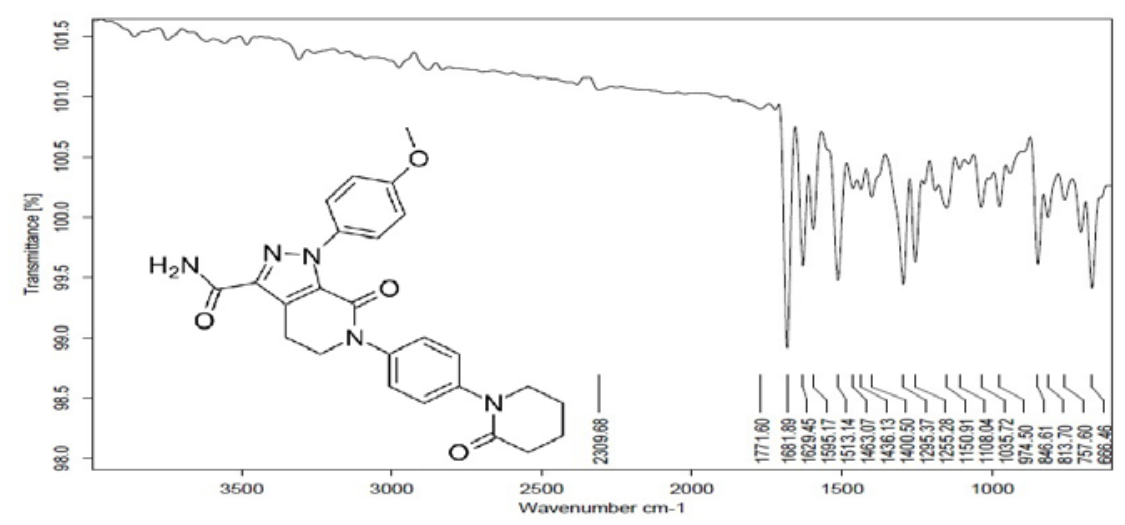

Fig. 2: IR spectrum of apixaban 


\section{RESULTS AND DISCUSSION}

\section{Formulation of tablets}

Apixaban was found to be soluble in acetonitrile. Drug-excipients interaction studies were performed using FTIR spectrophotometer.
The FTIR spectra for the formulation and pure drug are shown in fig. 2 and fig. 3. Characteristics peaks obtained for the pure drug correlated well with that of the formulation peaks.

This indicated that the drug was compatible with the formulation components.

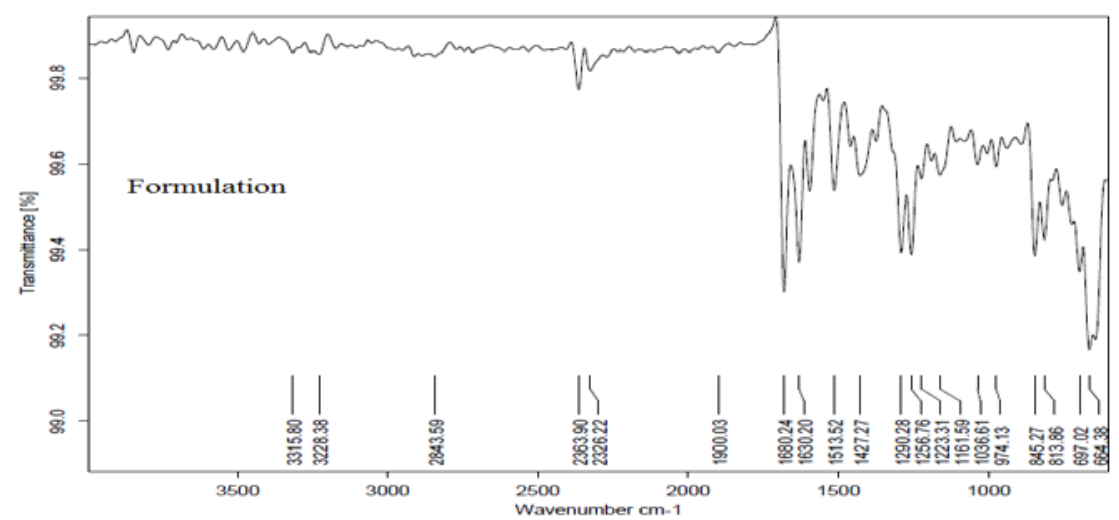

Fig. 3: IR spectrum of apixaban formulation

\section{Evaluation of powder blend}

The angle of repose of all formulations was between $21.37^{\circ}$ to $28.14^{\circ}$, while the result of the Carr's index and Hausner ratio was between $11.71 \%$ to $20.02 \%$ and 1.03 to 1.25 , respectively.
Evaluation of powder blend characteristics is presented in table 3. The results indicate that the prepared powder mixtures have acceptable flow properties and compressibility. All precompression parameters are found to be within the acceptance criteria.

Table 2: Evaluation of powder blend characteristics

\begin{tabular}{|c|c|c|c|c|c|c|c|c|c|}
\hline Parameters & F1 & F2 & F3 & F4 & F5 & F6 & F7 & F8 & F9 \\
\hline Angle of Repose & $23.05^{\circ}$ & $22.89^{\circ}$ & $23.49^{\circ}$ & $21.37^{\circ}$ & $25.55^{\circ}$ & $25.01^{\circ}$ & $27.07^{\circ}$ & $27.09^{\circ}$ & $28.14^{\circ}$ \\
\hline Bulk Density & 0.606 & 0.571 & 0.588 & 0.606 & 0.588 & 0.588 & 0.588 & 0.571 & 0.588 \\
\hline Tapped Density & 0.689 & 0.714 & 0.666 & 0.714 & 0.689 & 0.714 & 0.666 & 0.714 & 0.689 \\
\hline Hausner's Ratio & 1.13 & 1.25 & 1.13 & 1.17 & 1.17 & 1.21 & 1.03 & 1.25 & 1.17 \\
\hline \% Carr's Index & 12.04 & 12.02 & 11.71 & 15.12 & 14.65 & 17.64 & 17.97 & 20.02 & 14.65 \\
\hline
\end{tabular}

$(n=3)$

\section{Evaluation of tablets}

The evaluation parameters of all formulation batches are presented in table 3. The thickness of tablets was observed in the range of $2.4 \pm 0.172$ to $2.5 \pm 0.171 \mathrm{~mm}$, it was found that all prepared tablets had a uniform thickness. The hardness of tablets was in the range of $3.4 \pm 0.05$ to $3.7 \pm 0.10 \mathrm{~kg} / \mathrm{cm}^{2}$, which shows sufficient mechanical strength. The total weight loss of the prepared tablets due to friability was found in the range of $0.50 \%$ to $0.80 \%$, which is within acceptance criteria. The weight variation of prepared tablets was in the range of $98.43 \pm 0.61$ to $100.82 \pm 0.79$. The content uniformity of the prepared tablets was in the range of $93.98 \pm 1.32 \%$ to $95.25 \pm 1.12 \%$, which reveals content uniformity. All evaluation parameters were found within the acceptance criteria.

Table 3: Evaluation of formulation batches of tablets

\begin{tabular}{|c|c|c|c|c|c|c|c|c|c|}
\hline Parameters & F1 & F2 & F3 & F4 & F5 & F6 & F7 & F8 & F9 \\
\hline $\begin{array}{l}\text { Thickness } \\
(\mathrm{mm})^{*}\end{array}$ & $2.5 \pm 0.18$ & $2.4 \pm 0.17$ & $2.5 \pm 0.17$ & $2.5 \pm 0.17$ & $2.4 \pm 0.17$ & $2.4 \pm 0.17$ & $2.4 \pm 0.17$ & $2.5 \pm 0.17$ & $2.5 \pm 0.17$ \\
\hline Weight & $98.43 \pm 0.6$ & $99.06 \pm 0.7$ & $99.08 \pm 0.7$ & $99.41 \pm 0.9$ & $100.11 \pm 0.8$ & $99.49 \pm 0.8$ & $100.6 \pm 0.8$ & $100.82 \pm 0.7$ & $100.48 \pm 0.6$ \\
\hline $\begin{array}{l}\text { Variation } \\
\text { (mg)* }\end{array}$ & 1 & 8 & 2 & 3 & 4 & 3 & 1 & 9 & 7 \\
\hline $\begin{array}{l}\text { Hardness } \\
\mathrm{kg} / \mathrm{cm}^{2 *}\end{array}$ & $3.4 \pm 0.05$ & $3.6 \pm 0.05$ & $3.5 \pm 0.15$ & $3.5 \pm 0.05$ & $3.6 \pm 0.20$ & $3.5 \pm 0.05$ & $3.7 \pm 0.10$ & $3.4 \pm 0.05$ & $3.6 \pm 0.20$ \\
\hline Friability (\%) & 0.50 & 0.60 & 0.80 & 0.60 & 0.80 & 0.60 & 0.60 & 0.60 & 0.50 \\
\hline $\begin{array}{l}\text { Disintegratio } \\
\mathrm{n} \text { test }\end{array}$ & $138 \pm 1.15$ & $137 \pm 1.80$ & $136 \pm 2.11$ & $137 \pm 1.45$ & $136 \pm 1.23$ & $139 \pm 2.10$ & $140 \pm 2.40$ & $145 \pm 1.76$ & $139 \pm 1.32$ \\
\hline $\begin{array}{l}\text { Content } \\
\text { uniformity }\end{array}$ & $\begin{array}{l}94.62 \pm 0.5 \\
4\end{array}$ & $\begin{array}{l}94.62 \pm 1.8 \\
5\end{array}$ & $\begin{array}{l}94.62 \pm 1.6 \\
8\end{array}$ & $\begin{array}{l}94.30 \pm 0.7 \\
2\end{array}$ & $93.98 \pm 1.32$ & $\begin{array}{l}94.62 \pm 1.8 \\
7\end{array}$ & $\begin{array}{l}95.25 \pm 1.1 \\
2\end{array}$ & $94.93 \pm 0.43$ & $95.25 \pm 1.85$ \\
\hline $\begin{array}{l}\text { In vitro } \\
\text { Dissolution } \\
\text { Studies }\end{array}$ & 36.48 & 40.25 & 29.97 & 38.95 & 90.979 & 69.25 & 62.55 & 44.59 & 67.57 \\
\hline
\end{tabular}

$\left({ }^{*} \mathrm{n}=3\right)$ data represented as mean $\pm \mathrm{SD}$ 


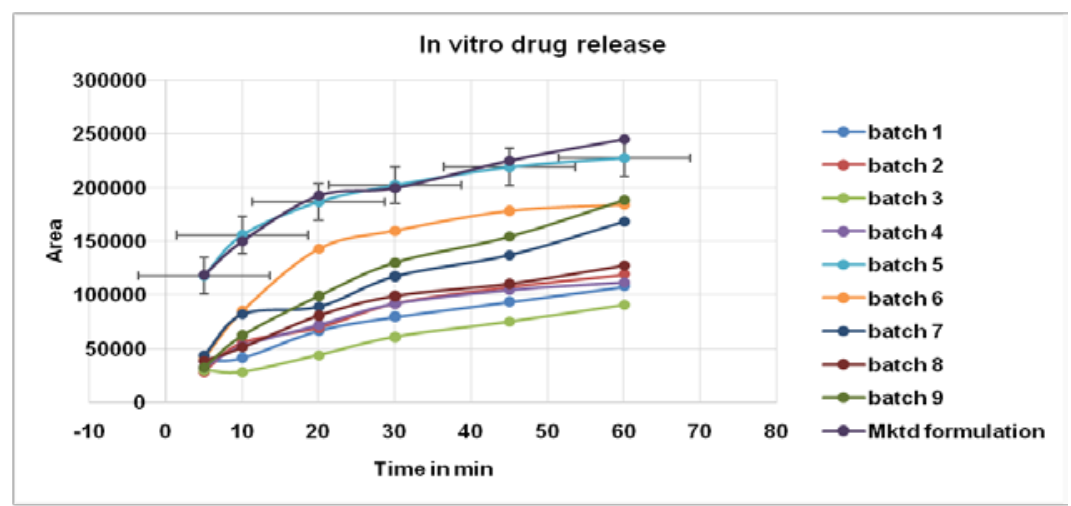

Fig. 4: Graphical representation of in vitro dissolution of all batches

From the dissolution study (fig. 4), it is observed that formulation batch F5 shows maximum drug release pattern as compared to other formulations. Therefore, this batch was selected as optimized formulation batch.

\section{Difference and similarity factor [15]}

Results obtained from the dissolution profile were fitted into equations (1) and (2) to determine the difference and similarity factors of the various batches compared to standard. Difference and similarity factors are the model-independent approach used to estimate the differential factor (f1) and similarity factor (f2) to compare the dissolution profile of optimized formulation (F5) with innovator product. The difference between the reference and test curve at each time point and is a measurement of the relative error between two curves. The FDA suggested that two dissolution profiles were declared similar if the $\mathrm{f} 2$ value between $50-100$ and $\mathrm{f} 1$ was $0-15$.

$\mathrm{f} 1=\{[\Sigma \mathrm{t}=1 \mathrm{n}|\mathrm{Rt}-\mathrm{Tt}|] /[\Sigma \mathrm{t}=1 \mathrm{n} \mathrm{Rt}]\} \times 100-$ Equation (1)

$\mathrm{f} 2=50+\log \{[1+(1 / \mathrm{n}) \Sigma \mathrm{t}=1 \times \mathrm{n}(\mathrm{Rt}-\mathrm{Tt}) 2]\}-0.5 \times 100-$ Equation (2)

Where,

$\mathrm{f} 1$ = difference factor, $\mathrm{f} 2$ = similarity factor, $\mathrm{n}=$ time points

$\mathrm{Rt}=$ cumulative percentage dissolved at time $\mathrm{t}$ for the reference

$\mathrm{Tt}=$ cumulative percentage dissolved at time $\mathrm{t}$ for the test.

Observations and calculations of difference and similarity factors are shown in table 4 and table 5 , respectively.

Table 4: Observation of $\%$ cumulative release of the Marketed and In-house formulation

\begin{tabular}{llllll}
\hline $\begin{array}{l}\text { S. } \\
\text { No. }\end{array}$ & $\begin{array}{l}\text { Time in } \\
\text { min }\end{array}$ & $\begin{array}{l}\text { Area of marketed } \\
\text { formulation }\end{array}$ & $\begin{array}{l}\text { Area of In-house } \\
\text { formulation }\end{array}$ & $\begin{array}{l}\text { \% cumulative release of } \\
\text { marketed formulation }\end{array}$ & $\begin{array}{l}\text { \% cumulative release of in- } \\
\text { house formulation }\end{array}$ \\
\hline 1 & 5 & 111842 & 117498 & 39.5050 & 41.8812 \\
2 & 10 & 150023 & 155680 & 55.9835 & 78.3861 \\
3 & 20 & 192447 & 186791 & 74.4224 & 72.0990 \\
4 & 30 & 199518 & 202346 & 78.2079 & 87.4224 \\
5 & 45 & 224972 & 219315 & 89.7492 & 90.9769 \\
6 & 60 & 244770 & 227800 & 98.0660 & \\
\hline
\end{tabular}

Table 5: Calculation of difference and similarity factors

\begin{tabular}{|c|c|c|c|c|}
\hline Time & Rt & $\mathbf{T t}$ & $\{$ Rt-Tt $\}$ & $(\mathrm{Rt}-\mathrm{Tt})^{2}$ \\
\hline 5 & 39.5050 & 41.8812 & 2.37623762 & 5.6465052 \\
\hline 10 & 55.9835 & 58.3861 & 2.40264026 & 5.7726802 \\
\hline 20 & 74.4224 & 72.0990 & 2.32343234 & 5.3983379 \\
\hline 30 & 78.2079 & 79.4224 & 1.21452145 & 1.4750624 \\
\hline 45 & 89.7492 & 87.4125 & 2.33663366 & 5.4598569 \\
\hline \multirow[t]{6}{*}{60} & 98.0660 & 90.9769 & 7.08910891 & 50.255465 \\
\hline & & sum (Rt-Tt) & & 17.742574 \\
\hline & & $\operatorname{sum}(\mathrm{Rt}-\mathrm{Tt})^{2}$ & & 74.007908 \\
\hline & & sum Rt & & 435.93399 \\
\hline & & Similarity factor f2 & & 70.0325 \\
\hline & & Difference factor f1 & & 4.0700 \\
\hline
\end{tabular}

The marketed formulation and in-house formulation shows similarity factor of 70.03 and differential factor of 4.07 . The similarity factor (f2) and differential factor (f1) was found within the acceptance criteria.

\section{Optimization of chromatographic conditions}

UV spectrum of apixaban showed maximum absorbance was found at $280 \mathrm{~nm}$. Hence, $280 \mathrm{~nm}$ was selected for detection wavelength of this drug. Initially, various chromatographic conditions were tried in order to obtain better separation characteristics by changing mobile phase composition and $\mathrm{pH}$. Finally, the mobile phase containing water: acetonitrile $(60: 40 \mathrm{v} / \mathrm{v})+0.1 \%$ TEA was selected at $1 \mathrm{ml} / \mathrm{min}$ flow rate. The retention time of apixaban was found to be $5.66 \mathrm{~min}$. The chromatogram of apixaban is shown in fig. 5 and optimized chromatographic conditions are mentioned in table 6 .

\section{Assay of tablet formulation}

The drug content was calculated as an average of three determinations and assay results were shown in table 7 . The results were very close to the labeled value of commercial tablets. The value of mean $\%$ drug was found to be $99.31 \%$ which is within acceptance criteria.

\section{Forced degradation studies}

Chromatograms obtained under different stress conditions like acidic, alkaline hydrolysis, oxidative, thermal and photolytic degradation are presented in fig 6(a), 6(b), 6(c), 6(d) and 6(e). 
Table 6: Optimized chromatographic conditions

\begin{tabular}{ll}
\hline Parameters & Details \\
\hline Mobile phase & Water: Acetonitrile $(60: 40) \mathrm{v} / \mathrm{v}+0.1 \% \mathrm{TEA}$ \\
Column & Purospher Star RP-18 end-capped $(5 \mu \mathrm{m})$ Hibar $250 \times 4,6$ \\
Flow rate & $1 \mathrm{ml} / \mathrm{min}$ \\
Detection & $280 \mathrm{~nm}$ \\
Injection volume & $20 \mu \mathrm{l}$ \\
Run time & $8 \mathrm{~min}$ \\
Retention time & $5.66 \mathrm{~min}$ \\
Diluent & water: acetonitrile $(60+40) \mathrm{v} / \mathrm{v}+0.1 \% \mathrm{TEA}$ \\
\hline
\end{tabular}

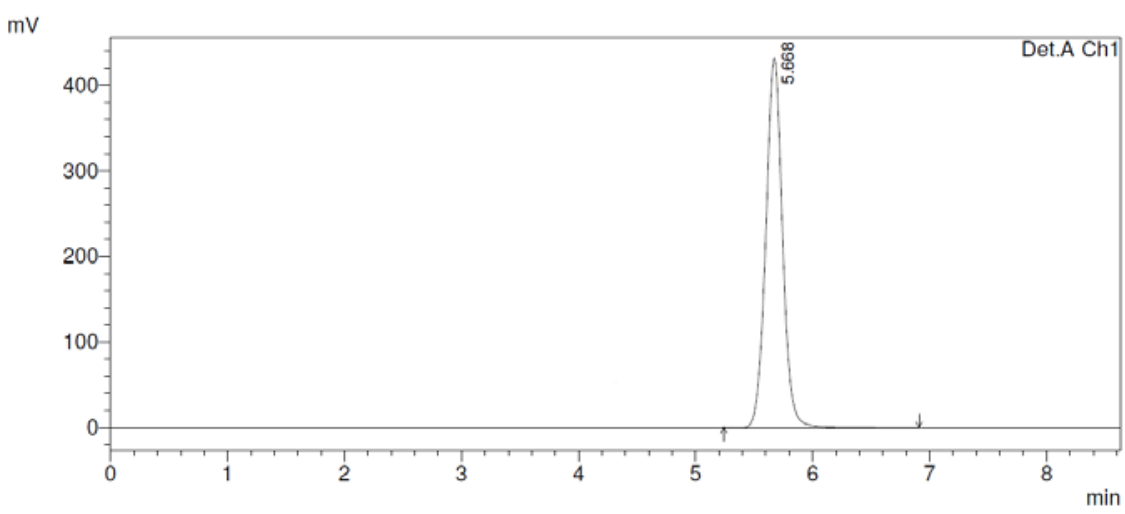

Fig. 5: Chromatogram of apixaban

Table 7: Results of assay of apixaban

\begin{tabular}{llll}
\hline S. No. & Sample solution concentration $(\boldsymbol{\mu g} / \mathbf{m l})$ & Actual concentration found & Amount of drug estimated mean \pm SD* \\
\hline 1 & 30 & 29.82 & $99.31 \pm 0.16$ \\
2 & 30 & 29.74 & \\
3 & 30 & 29.81 & \\
\hline
\end{tabular}

*The value is represented as a mean \pm SD of 3 observations.

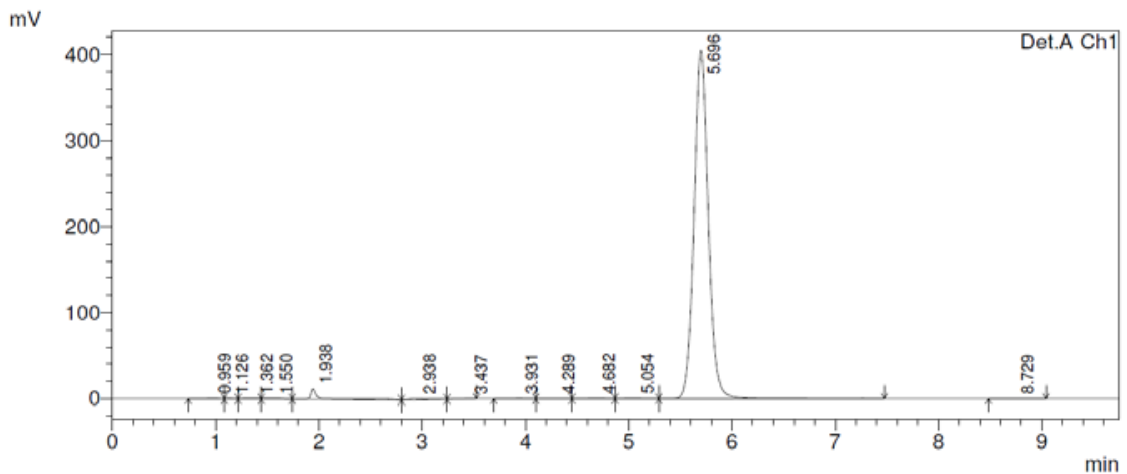

Fig. 6(a)

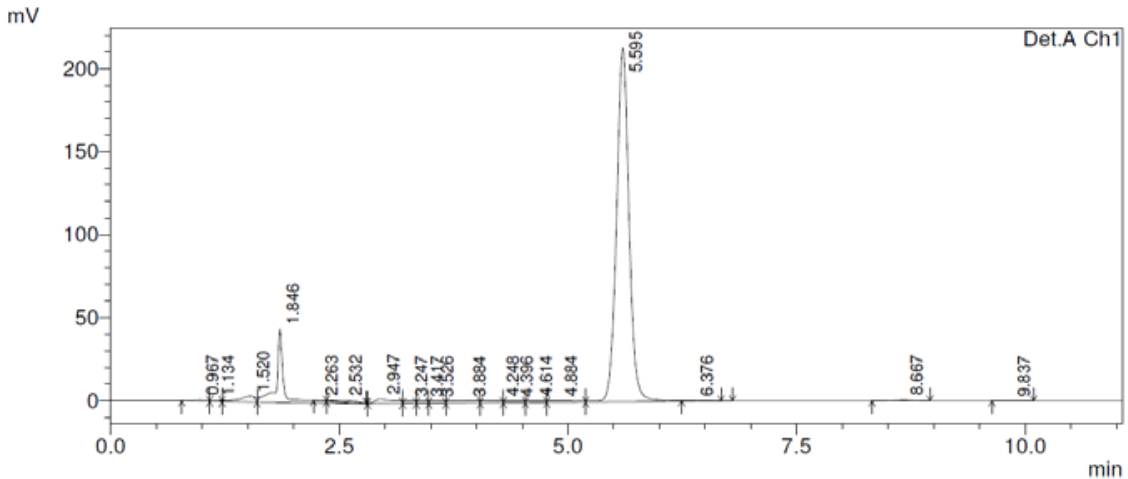

Fig. 6 (b) 


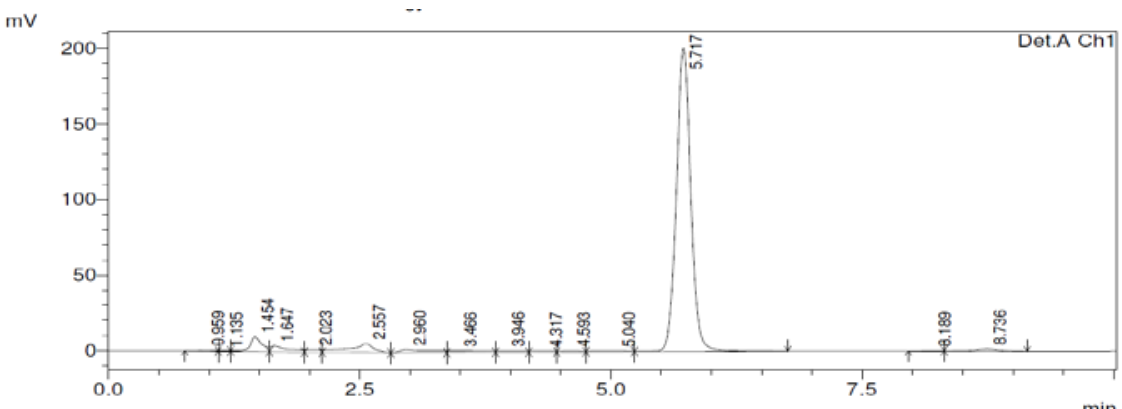

Fig. 6 (c)

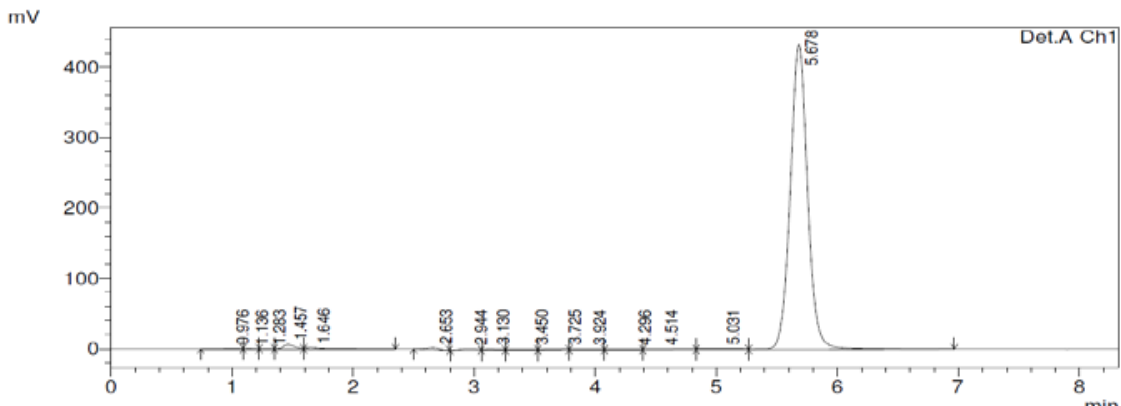

Fig. 6 (d)

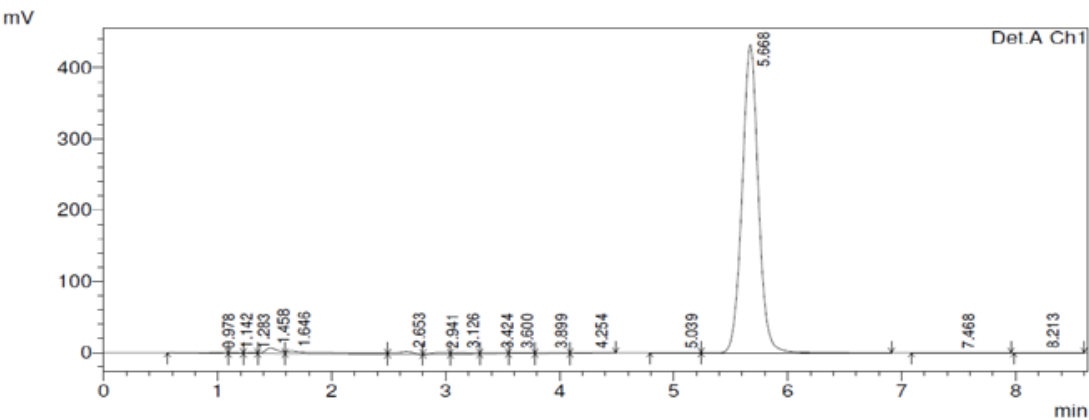

Fig. 6 (e)

Fig. 6: Typically degradation chromatograms of apixaban; (A): in $0.1 \mathrm{HCl}$ at $80^{\circ} \mathrm{C}$ after $2 \mathrm{~h}$. (B): in $0.1 \mathrm{~N} \mathrm{NaOH}$ at $80^{\circ} \mathrm{C}$ after $2 \mathrm{~h}$. (C): in $3 \%$ $\mathrm{H}_{2} \mathrm{O}_{2}$ at $80^{\circ} \mathrm{C}$ after $2 \mathrm{~h}$. (D): in dry heat at $80^{\circ} \mathrm{C}$ after $2 \mathrm{~h}$. (E): exposure to UV radiations for $12 \mathrm{~h}$

The first chromatogram obtained by acid hydrolysis [fig. 6(a)] suggested that $9.15 \%$ degradation of the drug was found, when refluxed at $80^{\circ} \mathrm{C}$ for $2 \mathrm{~h}$ in $0.1 \mathrm{~N} \mathrm{HCl}$. The major degradation product formed was at 1.938 min retention time. This study indicates that apixaban was susceptible to acid hydrolysis. Second chromatogram obtained by alkaline hydrolysis [fig. 6(b)] indicated that apixaban was not stable to alkaline hydrolysis when refluxed at $80^{\circ} \mathrm{C}$ for $2 \mathrm{~h}$ in $0.1 \mathrm{~N} \mathrm{NaOH}$. The Value of \% degradation was found to be $14.86 \%$ and major degradation products appeared at 1.84 and $2.94 \mathrm{~min}$ retention time. The third chromatogram obtained by oxidative degradation [fig. 6(c)] suggested that $4.15 \%$ degradation was observed when refluxed with $3 \% \mathrm{H}_{2} \mathrm{O}_{2}$ at $80{ }^{\circ} \mathrm{C}$ for $2 \mathrm{~h}$. The major degradation products appeared at 1.45, 1.64 and 2.55 min retention time. Fourth chromatogram obtained by thermal degradation [fig. 6 (d)] indicated that apixaban is less degraded when refluxed at $80{ }^{\circ} \mathrm{C}$ for $2 \mathrm{~h}$. The minor degradation product was obtained at $1.45 \mathrm{~min}$ retention time. Fifth chromatogram obtained by photolytic degradation [fig. 6(e)] indicated that apixaban is less degraded upon exposure to UV radiations for $12 \mathrm{~h}$. The minor degradation product was obtained at $1.45 \mathrm{~min}$ retention time.

\section{Validation of the method}

The developed chromatographic method was validated for linearity, range, accuracy, precision, LOD-LOQ and robustness parameters as per ICH guidelines.

\section{Linearity and range}

The value of correlation coefficient for apixaban (fig. 7) demonstrated the good relationship between peak areas and concentrations. Therefore, the developed method was linear in the concentration range of $5-30 \mu \mathrm{g} / \mathrm{ml}$.

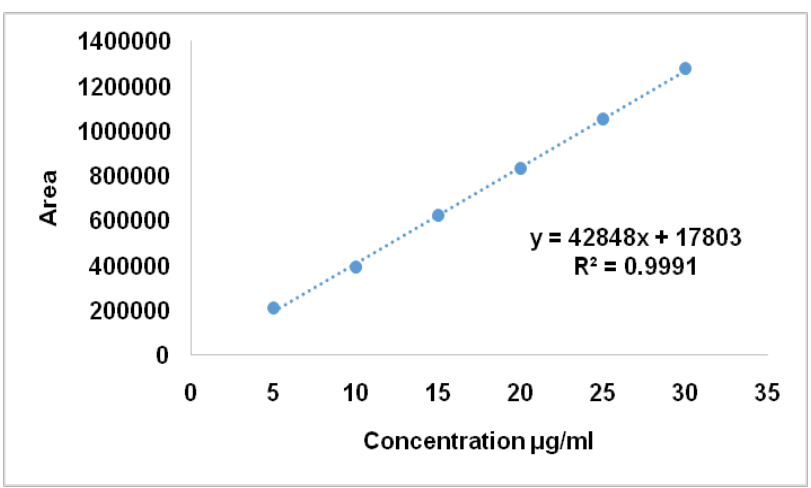

Fig. 7: Calibration curve of apixaban in acetonitrile: water $(60: 40 \mathrm{v} / \mathrm{v})$ 


\section{Precision}

The repeatability, intra-day precision was calculated as the relative standard deviation of results from three samples, during the same day, and the inter-day precision was studied by comparing on two different days. The percent relative standard deviation (\% RSD) was calculated which is within the acceptable criteria of not more than 2 were shown in table 8.

Table 8: Repeatability and intermediate precision for apixaban

\begin{tabular}{llll}
\hline Precision & Concentration of drug $(\boldsymbol{\mu g} / \mathbf{m l})$ & Mean area \pm SD* & \% RSD \\
\hline Repeatability* & 20 & $799859 \pm 1636.10$ & 0.37 \\
Intra-d & 10 & $377252 \pm 6808.76$ & 1.80 \\
& 20 & $835741 \pm 3499.53$ & 0.42 \\
Inter-d & 30 & $121438 \pm 2744.61$ & 0.23 \\
& 10 & $373366 \pm 3209.56$ & 0.86 \\
& 20 & $801115 \pm 8040.09$ & 0.10 \\
\end{tabular}

*Each value is represented as a mean $\pm \mathrm{SD}$ of $\mathrm{n}$ observations. The value of $\mathrm{n}$ is 6 for repeatability study and 3 for intraday and interday precision. SD: Standard deviation, \%RSD: Percent relative standard deviation

\section{Accuracy}

The accuracy was determined by the standard addition method. Amounts of $6 ; 10 ; 14 \mu \mathrm{g} / \mathrm{ml}$ of the apixaban standard were added to the sample solution in which $10.0 \mu \mathrm{g} / \mathrm{ml}$ of the drug had been incorporated previously. The final concentrations of the fortified solutions were $16.0,20.0$ and $24.0 \mu \mathrm{g} / \mathrm{ml}$ of apixaban. The recovery experiments were performed in triplicate for each concentration. The value of mean \% recovery and \% RSD (table 9) at each level was found within acceptance criteria that indicate the method is accurate.

Table 9: Accuracy of apixaban

\begin{tabular}{|c|c|c|c|c|}
\hline Levels & Amount taken $(\mu \mathrm{g} / \mathrm{ml})$ & Amount found $(\mu \mathrm{g} / \mathrm{ml})$ & $\%$ recovery & $\%$ Mean recovery $\pm \%$ RSD \\
\hline \multirow[t]{3}{*}{$80 \%$} & & 16.36 & 102.2 & $101.25 \pm 0.17$ \\
\hline & 16 & 15.72 & 98.25 & \\
\hline & & 16.54 & 103.3 & \\
\hline \multirow[t]{3}{*}{$100 \%$} & & 19.36 & 96.8 & $96.1 \pm 0.63$ \\
\hline & 20 & 19.15 & 95.75 & \\
\hline & & 19.15 & 95.75 & \\
\hline \multirow[t]{3}{*}{$120 \%$} & & 27.88 & 92.93 & $93.03 \pm 0.13$ \\
\hline & 24 & 27.95 & 93.16 & \\
\hline & & 27.90 & 93.00 & \\
\hline
\end{tabular}

*Percent recovery was done in triplicate, \% recovery: Percent recovery, \%RSD: Percent relative standard deviation

\section{Robustness}

Robustness was performed by changing various method parameters like a change in flow rate, the composition of mobile phase and change in detection wavelength. Finally, the effect of these changes was not deliberate. The value of \% RSD (table 10) was found to be within acceptance criteria which showed the reliability of the method.

Table 10: Robustness study of apixaban

\begin{tabular}{ll}
\hline Parameters & \% RSD \\
\hline A: Change in flow rate & $1.98 \%$ \\
$0.9 \mathrm{ml} / \mathrm{min}$ & \\
$1 \mathrm{ml} / \mathrm{min}$ & \\
$1.1 \mathrm{ml} / \mathrm{min}$ & $1.64 \%$ \\
B: Change in Mobile Phase \\
Water: ACN $(55: 45) \mathrm{v} / \mathrm{v}+0.1 \%$ TEA \\
Water: ACN $(60: 40) \mathrm{v} / \mathrm{v}+0.1 \%$ TEA \\
Water: ACN $(65: 35) \mathrm{v} / \mathrm{v}+0.1 \%$ TEA \\
C: Change in wavelength \\
$279 \mathrm{~nm}$ \\
$280 \mathrm{~nm}$
\end{tabular}

*Each value is represented as \% RSD of $\mathrm{n}$ observations. The value of $\mathrm{n}$ is 3 for change in flow rate, change in wavelength and change in mobile phase composition. \%RSD: Percent relative standard deviation

\section{Limit of detection (LOD) and limit of quantitation (LOQ)}

The sensitivity of measurement of apixaban by use of proposed methods was estimated in terms of the limit of quantitation (LOQ) and limit of detection (LOD). The values of LOD and LOQ have been found to be $1.020 \mu \mathrm{g} / \mathrm{ml}$ and $3.091 \mu \mathrm{g} / \mathrm{ml}$, respectively. These values show that method is sensitive.

\section{CONCLUSION}

A cost-effective formulation of apixaban tablets was developed by $3^{2}$ factorial design. Results of formulation evaluation of prepared between indicate that batch F5 is a promising formulation for the immediate release of the drug. Results obtained by validation studies suggested that the developed stability indicating assay 
method is simple, accurate, specific and precise. Thus, this method can be used for routine analysis of apixaban formulation and to check the stability testing.

\section{ACKNOWLEDGEMENT}

Authors thank Principal, Sinhgad College of Pharmacy, Pune for providing required facility to complete this project.

\section{AUTHOR CONTRIBUTION}

Both authors contributed equally to this work

\section{CONFLICT OF INTERESTS}

Declared none

\section{REFERENCES}

1. Pinto DJ, Orwat MJ, Koch S, Rossi KA, Alexander RS, Smallwood A, Wong PC, et al. Discovery of 1-(4-methoxyphenyl)-7-oxo-6-(4-(2oxopiperidin-1-yl) phenyl)-4, 5, 6, 7-tetrahydro-1 H-pyrazolo [3, 4c] pyridine-3-carboxamide (Apixaban, BMS-562247), a highly potent, selective, efficacious and orally bioavailable inhibitor of blood coagulation factor Xa. J Med Chem 2007;50:5339-56.

2. Lassen MR, Davidson BL, Gallus A, Pineo G, Ansell J, Deitchman $D$. The efficacy and safety of apixaban, an oral, direct factor Xa inhibitor, as thromboprophylaxis in patients following total knee replacement. J Thromb Haemostasis 2007;5:2368-75.

3. FDA approves apixaban for stroke prevention in nonvalvular AF-Medscape; 2012. p. 28.

4. Landge SB, Jadhav SA, Dahale SB, Solanki PV, Bembalkar SR, Mathad VT. Development and validation of stability indicating RP-HPLC method on core-shell column for determination of degradation and process related impurities of the apixaban-an anticoagulant drug. Am J Anal Chem 2015;6:539-50.

5. Prabhune SS, Jaguste RS, Kondalkar PL, Pradhan NS. Stabilityindicating high-performance liquid chromatographic determination of apixaban in presence of degradation products. Sci Pharm 2014;82:777-85.

6. Katta R, Nagaraju C, Ramashrinivas, Rao GN. Two novel validated RP-HPLC and UV spectrophotometric methods for estimation of apixaban in bulk and pharmaceutical dosage forms. Am J PharmTech Res 2015;5:4.

7. Zhang W, Lou D, Zhang D, Zhang Y, Huang H. 'Determination of rivaroxaban, apixaban and edoxaban in rat plasma by UPLCMS/MS method. J Thromb Thrombolysis 2016;42:205-11.

8. Schmitz E, Boonen $\mathrm{K}$, van den Heuvel D, van Dongen J, Schellings M, Emmen J, et al. Determination of dabigatran, rivaroxaban and apixaban by ultra-performance liquid chromatography-tandem mass spectrometry (UPLC-MS/MS) and coagulation assays for therapy monitoring of novel direct oral anticoagulants. J Thromb Haemost 2014;12:1636-46.

9. Delavenne X, Mismetti P, Basset T. Rapid determination of apixaban concentration in human plasma by liquid chromatography/tandem mass spectrometry: application to pharmacokinetic study. J Pharm Biomed Anal 2013;7879:150-3.

10. Tilea I. Determination of apixaban levels in human plasma by a high-throughput liquid chromatographic tandem mass spectrometry assay. Rev Romana Med Lab 2015;23. https://doi.org/10.1515/rrlm-2015-0006

11. Tantawy MA, El-Ragehy NA, Hassan NY, Abdelkawy M. Stability-indicating spectrophotometric methods for determination of the anticoagulant drug apixaban in the presence of its hydrolytic degradation product. Spectrochim Acta Mol Biomol Spectrosc 2016;159:13-20.

12. Sutradhar KB, Akhter DT, Uddin R. Formulation and evaluation of taste masked oral dispersible tablets of domperidone using sublimation method. Int J Pharm Pharm Sci 2012;4:727-32.

13. Rath S, Gupta BK, Bala NN, Dhal HC. Formulation and optimization of immediate release telmisartan tablets using full factorial design. Int J Appl Pharm 2011;3:20-4.

14. India Pharmacopoeia, Ministry of Health and Family Welfare, New Delhi; Govt. of India, Controller of Publications; 2007. p. 177-83.

15. United States of Pharmacopeia-National Formulary. USP 30NF-25. The United States Pharmacopeial Convention, Rockville, MD; 2007;1:644, 242, 645, 731, 634.

16. Sree Giri Prasad B, Gupta VRM, Devanna N, Rama Devi M, Tamilselvan A, Siva Subramanian N. Formulation and evaluation of clopidogrel bisulfate Immediate release tablets. J Global Trends Pharm Sci 2014;5:2154-66.

17. ICH Harmonized-Tripartite Guidelines, Stability Testing of New Drug Substance And Products, Q1A (R2); 2003.

18. Naazneen S, Sridevi A. Development of assay method and forced degradation study of valsartan and sacubitril by RPHPLC in tablet formulation. Int J Appl Pharm 2017;9:9-15.

19. Jain HK, Gujar KN, Randhe VA. Stability indicating RP-HPLC assay method for estimation of midodrine hydrochloride in bulk and tablets. Int J Pharm Pharm Sci 2016;8:283-7.

20. Bakshi M, Singh S. Development of validated stabilityindicating assay methods-critical review. J Pharm Biomed Anal 2002;28:1011-40.

21. Jain HK, Ranjale AR. Development and validation of a RP-HPLC method for simultaneous estimation of cefoperazone and tazobactam in the marketed formulation. Int J Pharm Pharm Sci 2014;6:462-5.

22. Devkare PN, Jain HK. Development and validation of a RP-HPLC method for simultaneous estimation of S(-) amlodipine besylate and clopidogrel bisulphate in tablet dosage form. Int I Pharm Pharm Sci 2013;5:770-5.

23. ICH Harmonized-Tripartite Guidelines, Validation of Analytical Procedure: Text and Methodology Q2(R1); 2005.

\section{How to cite this article}

- Hemant K Jain, Vishal K Nikam. Formulation development and stability indicating HPLC assay of tablets of apixaban. Int J Pharm Pharm Sci 2017;9(10):24-32. 